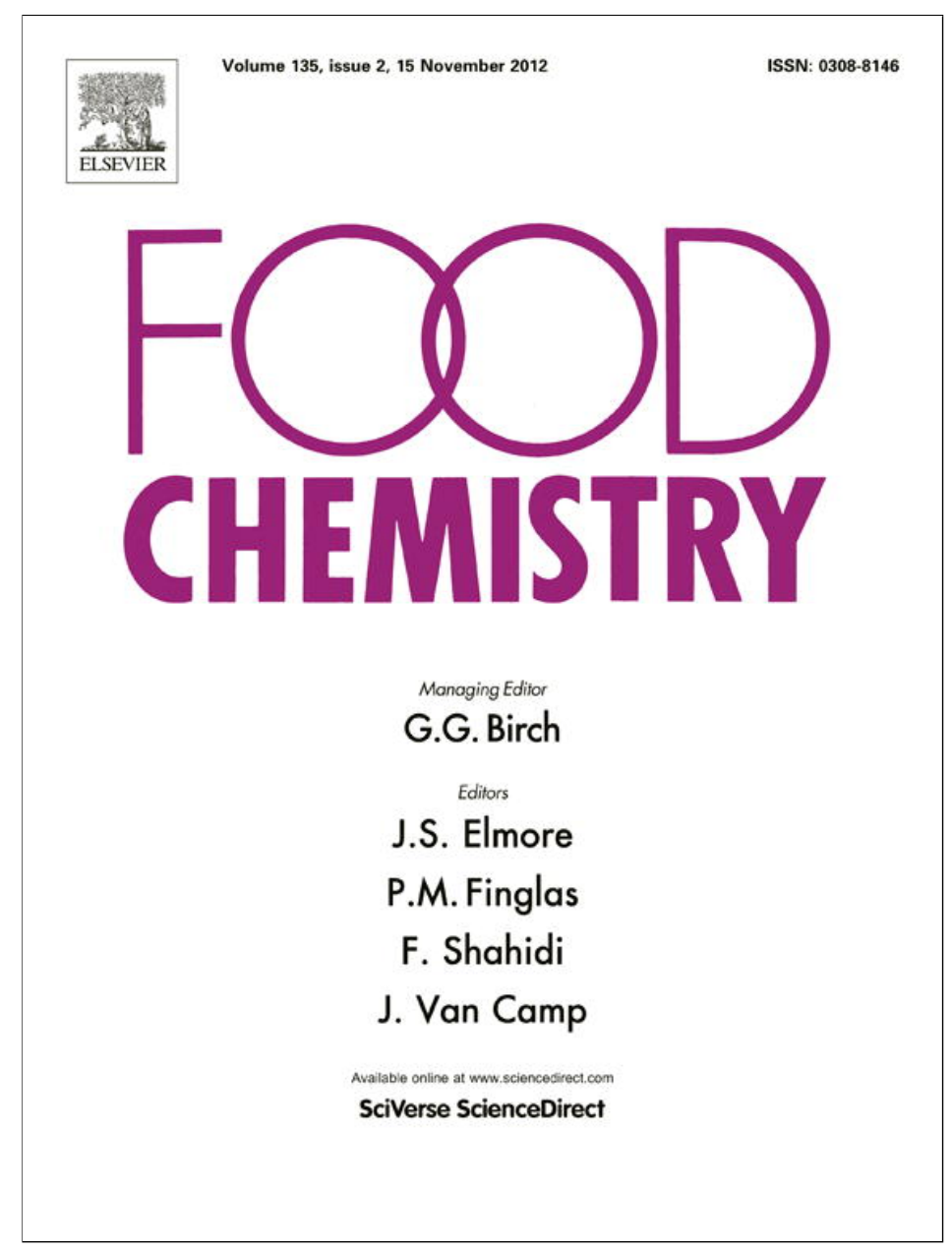

This article appeared in a journal published by Elsevier. The attached copy is furnished to the author for internal non-commercial research and education use, including for instruction at the authors institution and sharing with colleagues.

Other uses, including reproduction and distribution, or selling or licensing copies, or posting to personal, institutional or third party websites are prohibited.

In most cases authors are permitted to post their version of the article (e.g. in Word or Tex form) to their personal website or institutional repository. Authors requiring further information regarding Elsevier's archiving and manuscript policies are encouraged to visit:

http://www.elsevier.com/copyright 


\title{
Interaction of phenolic compounds with bovine serum albumin (BSA) and $\alpha$-amylase and their relationship to astringency perception
}

\author{
Raúl Ferrer-Gallego a , Rui Gonçalves ${ }^{\text {b }}$, Julián Carlos Rivas-Gonzalo a , María Teresa Escribano-Bailón ${ }^{\mathrm{a}, *}$, \\ Victor de Freitas ${ }^{b}$ \\ a Grupo de Investigación en Polifenoles, Unidad de Nutrición y Bromatología, Facultad de Farmacia, Universidad de Salamanca, Campus Miguel de Unamuno, E 37007 Salamanca, Spain

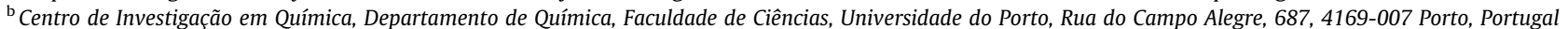

\section{A R T I C L E I N F O}

\section{Article history:}

Received 18 January 2012

Received in revised form 30 March 2012

Accepted 23 April 2012

Available online 30 April 2012

\section{Keywords:}

Grape seeds

Flavanols

Fluorescence quenching

Nephelometry

Astringency

\begin{abstract}
A B S T R A C T
The ability of grape seed extracts to bind to bovine serum albumin (BSA) and $\alpha$-amylase was studied by fluorescence quenching of protein intrinsic fluorescence and nephelometry. The influence of grape seed ripeness on astringency was also evaluated. From the spectra obtained, the modified Sterm-Volmer $\left(K_{\text {app }}\right)$ and the bimolecular quenching constants were calculated. Results showed that grape seed extracts had good affinity for proteins. The association strength of tannin-protein interactions varied with changes in tannin structure associated with the degree of ripeness affecting the binding/quenching process. In all cases studied, higher values of $K_{\text {app }}$ were obtained in samples at harvest which have greater ability to bind to proteins than have samples at post-veraison time. Nephelometric assays show the same trend as do fluorescence quenching studies. A possible explanation for this is that, as seeds ripen, their tannins increase in molecular mass, which relates to an increase in hydrophobicity of the molecules, and this increases protein affinity. However, that is contrary to the reported decrease in astringency of grape seeds during maturity. This indicates that tannin-protein interactions are not the only explanation for the complex sensations of astringency of grape seeds.
\end{abstract}

(c) 2012 Elsevier Ltd. All rights reserved.

\section{Introduction}

Tannins are phenolic compounds classically divided into two major groups: hydrolysable and condensed tannins, both having the ability to bind and precipitate proteins (Khanbabaee \& van Ree, 2001). Proanthocyanidins or condensed tannins are oligomers and polymers of flavan-3-ol units which are widely distributed in fruits, vegetables, nuts and beverages; they are present in the solid parts of the grapes, seeds, skins, leafs and stems (Kennedy, Matthews, \& Waterhouse, 2000; Prieur, Rigaud, Cheynier, \& Moutounet, 1994; Souquet, Cheynier, Brossaud, \& Moutounet, 1996; Souquet, Labarbe, Le Guerneve, Cheynier, \& Moutounet, 2000) and extracted during red wine making (Cadot, Minana-Castello, \& Chevalier, 2006; Sun, Pinto, Leandro, Ricardo Da Silva, \& Spranger, 1999). These compounds are responsible for important characteristics of wine, such as bitterness and astringency and are considered relevant to the long-term colour stability of red wines (Escribano-Bailón, Álvarez-García, Rivas-Gonzalo, Heredia, \& Santos-Buelga, 2001; Gawel, 1998). Generally, grape seed procyanidins exist in the form of oligomers (mainly dimers and trimers) and polymers composed of the monomeric flavan-3-ols (+)-catechin, (-)-epicatechin linked by $\mathrm{C} 4-\mathrm{C} 8$ and/or C4-C6 bonds

\footnotetext{
* Corresponding author. Tel.: +34 923294 537; fax: +34 923294515.

E-mail address: escriban@usal.es (M.T. Escribano-Bailón).
}

(B-type) (Escribano-Bailón, Gutiérrez-Fernández, Rivas-Gonzalo, \& Santos-Buelga, 1992; Jordao, Ricardo Da Silva, \& Laureano, 2001; Prieur et al., 1994). The flavan-3ols can also be esterified with gallic acid, forming 3-O-gallates (Da Silva, Rigaud, Cheynier, Cheminat, \& Moutounet, 1991; Passos, Cardoso, Barros, Silva, \& Coimbra, 2010; Santos-Buelga, Francia-Aricha, \& Escribano-Bailón, 1995). Levels of galloylated derivatives are usually present in smaller amounts than are the non-galloylated ones. (+)-Catechin is often the most abundant individual flavanol of seeds; dimers B2 and B4 and trimer C1 are usually well represented in their respective oligomer groups (Da Silva et al., 1991; Ricardo Da Silva, Rosec, Bourzeix, Mourgues, \& Moutonet, 1992; Sun et al., 1999). Quantity, structure and degree of polymerization of seed tannins are modified during ripening development (De Freitas, Glories, \& Monique, 2000; Downey, Harvey, \& Robinson, 2003; Kennedy et al., 2000; Obreque Slier, 2010; Romeyer, Macheix, \& Sapis, 1986) which affects their ability to bind to proteins (McRae, Falconer, \& Kennedy, 2010).

Tannins were shown to reduce saliva-lubricating ability, both by increasing friction and by reducing its viscosity (Prigent et al., 2009; Prinz \& Lucas, 2000). Some authors have shown that the interaction between tannin and salivary proteins is indeed involved in the mechanism of astringency (Horne, Hayes, \& Lawless, 2002; Kallithraka, Bakker, \& Clifford, 1998). In this way, several studies have been performed to correlate or predict the 
astringency by certain techniques based on the in vitro reactivity of polyphenols towards different proteins (Canon, Giuliani, Paté, \& Sarni-Manchado, 2010; Fia, Dinnella, Bertuccioli, \& Monteleone, 2009; Mateus \& De Freitas, 2001; McRae et al., 2010; Monteleone, Condelli, Dinnella, \& Bertuccioli, 2004; Obreque-Slier, López-Solís, Peña-Neira, \& Zamora-Marín, 2010; Papadopoulou \& Frazier, 2004; Papadopoulou, Green, \& Frazier, 2005; Petrovic, 2009). Fluorescence quenching and nephelometry are commonly used for this purpose (Carvalho et al., 2006; De Freitas, Carvalho, \& Mateus, 2003; Hofmann et al., 2006; Papadopoulou \& Frazier, 2004; Soares, Gonçalves, Fernandes, Mateus, \& de Freitas, 2009). Nephelometry is a particularly simple method that allows direct estimation of the amount of protein/tannin complexes (Mateus, Pinto, Ruão, \& de Freitas, 2004). Fluorescence measurements provide information about the molecular environment in the vicinity of the chromophore molecule. The decrease of protein intrinsic fluorescence intensity is called quenching, which can occur by different mechanisms, namely, collisional quenching, when the excited-state fluorophore is deactivated upon contact with some other molecule in solution (the quencher $[Q]$ ), or static quenching, whereby fluorophores form non-fluorescent complexes with quenchers.

Bovine serum albumin (BSA) and $\alpha$-amylase are globular proteins frequently used to study polyphenols/protein interactions (Papadopoulou \& Frazier, 2004; Papadopoulou et al., 2005; Soares et al., 2009). BSA, a single polypeptide chain, consists of 582 amino acid residues with two tryptophan residues in different environments (hydrophobic and hydrophilic environments), which are responsible for the intrinsic fluorescence. $\alpha$-Amylase is an abundant protein in saliva which constitutes around 30\% of total proteins (Elodis, Móra, \& Krysteva, 1972). $\alpha$-Amylase from porcine pancreas consists of 496 amino acid residues, forming a single polypeptide chain with 17 tryptophan residues with intrinsic fluorescence (Buisson, Duee, Haser, \& Payan, 1987; Pasero, MazzeiPierron, Abadie, \& Chicheportiche, 1986; Rawel, Frey, Meidtner, Kroll, \& Schweigert, 2006). Generally, it is considered that the porcine enzyme is very similar to human $\alpha$-amylase (Buisson et al., 1987).

It has been suggested that oral astringency results from the precipitation of salivary proteins. However, by itself this does not explain all aspects of astringency (Jackson, 2009) and it has been recently pointed out that tannin-protein interaction is more closely associated with astringency than is tannin-protein complex precipitation (Obreque-Slier et al., 2010). Nowadays, tannin-protein precipitation is questioned as an objective measure of sensory attributes (Obreque-Slier et al., 2010; Schwarz \& Hofmann, 2008) and sensory analysis is a useful tool for evaluating sensory properties (Le Moigne, Maury, Bertrand, \& Jourjon, 2008; Monteleone et al., 2004; Sáenz-Navajas, Ferreira, Dizy, \& Fernández-Zurbano, 2010).

The loss of salivary lubrication is not the only mechanism involved in the perception of astringency (Kallithraka, Bakker, \& Clifford, 1997; Payne, Bowyer, Herderich, \& Bastian, 2009; Rossetti, Bongaerts, Wantling, Stokes, \& Williamson, 2009); this phenomenon may also be due, at least in part, to binding of procyanidins or procyanidin-protein complex, to cells of the oral epithelium (Green, 1993; Nayak \& Carpenter, 2008; Payne et al., 2009). In fact, studies in breast and lung cancer cell lines have identified a receptor for epigallocatechin-gallate as the mammalian $67 \mathrm{kDa}$ laminin receptor (Tachibana, Koga, Fujimura, \& Yamada, 2004), a protein also found in the extracellular matrix of oral mucosa (Hakkinen, Uitto, \& Larjava, 2000). More recently, Payne et al. (2009) have demonstrated that procyanidins, present in a commercial grape extract, bind to oral epithelial cells in a dose-dependent manner.

The importance of wine astringency for marketability has led to a wealth of research on the causes of astringency and how tannins impact the quality of the sensation (McRae \& Kennedy, 2011). In this context, the aim of this work is to evaluate the ability of grape seed procyanidins to bind to proteins and how the different degrees of seed ripeness affect this interaction. For this, BSA and $\alpha$-amylase were used and fluorescence quenching and nephelometry techniques were applied. Moreover, a sensory analysis was performed in order to evaluate the levels of astringency and tannic intensity in grape seeds at two different developmental stages (post-veraison and harvest).

\section{Material and methods}

\subsection{Seed samples}

Vitis vinifera L. cv. "Graciano" red grapes were collected from two different vineyards located in P.O.D. La Rioja (Spain). Two vintages (2008-2009) and two different developmental stages (postveraison, ca. $15^{\circ}$ Brix, and harvest time, ca. $24{ }^{\circ}$ Brix) were taken into account for this study. In total, 300 berries per vineyard were collected at each date from both sides of vines located in different rows within the vineyard. Berries were collected and immediately tasted. For all other analyses, the samples were immediately frozen and stored at $-20^{\circ} \mathrm{C}$ until analyses were performed.

\subsection{Phenolic compounds extraction}

Phenolic extraction was carried out as described in Garcia-Marino, Rivas-Gonzalo, Ibañez, and Garcia-Moreno (2006). Briefly, grape seeds were separated manually and freeze-dried. Seeds were ground to obtain a homogeneous powder for extraction. The grape seed powder was extracted with $75 \%$ methanol. The methanolic extracts were concentrated at low pressure until an aqueous extract was obtained. All analyses were performed in triplicate.

\subsection{Reagents and chemical analysis}

Bovine serum albumin (BSA) (96\%), $\alpha$-amylase (98\%) from porcine pancreas and $(+)$-catechin $(98 \%)$ were purchased from Sigma. The phenolic compound identifications and quantifications were carried out in accordance with Ferrer-Gallego, García-Marino, Hernández-Hierro, Rivas-Gonzalo, and Escribano-Bailón (2010). LC-diode array detection (DAD) analysis was performed in a Hewlett-Packard 1200 series liquid chromatograph, and detection was carried out using a photodiode detector. A Spherisorb ${ }^{\circledR}$ S3 ODS-2 reverse phase $3 \mu \mathrm{m}$ particle size C18 column, $150 \times 4.6 \mathrm{~mm}$ i.d. (Waters, Ireland), thermostatted at $25^{\circ} \mathrm{C}$, was used.

The solvents used were: (A) $2.5 \%$ acetic acid, (B) $2.5 \%$ acetic acid/acetonitrile (90:10, v:v), and (C) HPLC-grade acetonitrile, establishing the following gradient: from $0 \%$ to $100 \%$ B for $5 \mathrm{~min}$, from $0 \%$ to $15 \%$ C for $25 \mathrm{~min}$, from $15 \%$ to $50 \%$ C for $5 \mathrm{~min}$, and iso-

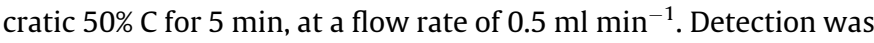
carried out at $280 \mathrm{~nm}$ as the preferred wavelength.

The mass analyses were performed using a Finnigan ${ }^{\mathrm{TM}}$ LCQ ion trap detector (Thermoquest, San Jose, CA, USA) equipped with an API source, using an electrospray ionisation (ESI) interface. The LC system was connected to the probe of the mass spectrometer via the UV cell outlet. Sheath gas and auxiliary gas were nitrogen and helium. The sheath gas flow was $1.21 \mathrm{~min}^{-1}$ and the auxiliary gas flow, $61 \mathrm{~min}^{-1}$. The source voltage and the capillary voltage used were $4.50 \mathrm{kV}$ and $28 \mathrm{~V}$, respectively, and the capillary temperature $270{ }^{\circ} \mathrm{C}$. Spectra were recorded in positive ion mode between $\mathrm{m} / \mathrm{z} 120$ and 2000.

\subsection{Statistical and chemometric analysis}

Significant differences were determined by one-way analysis of variance (ANOVA). Principal components analysis (PCA) was used 
for data analyses as an unsupervised pattern recognition method. The data matrix was constituted by sensory scores, nephelometry and fluorescence $\left(K_{\mathrm{app}}\right)$ values and phenolic composition. The aforementioned chemometric tool was applied to the correlation matrix of the original variables. All data were processed using the SPSS Program, version 13.0 for Windows software package (SPSS, Inc., Chicago, IL).

\subsection{Principles of fluorescence quenching (Lakowicz, 1999)}

Fluorescence quenching is described by the Stern-Volmer equation

$F_{0} / F=1+k_{q} \tau_{0}[Q]=1+K_{\mathrm{Sv}}[Q]$

where $F_{0}$ and $F$ are the fluorescence intensities before and after the addition of the quencher, respectively, $k_{\mathrm{q}}$ is the bimolecular quenching constant, $\tau_{0}$ is the lifetime of the fluorophore in the absence of quencher, $[Q]$ is the concentration of the quencher, and $K_{\mathrm{SV}}$ is the Stern-Volmer quenching constant. Hence, Eq. (1) was applied to determine $K_{\mathrm{SV}}$ by linear regression of a plot of $F_{0} / F$ against [Q].

A linear Stern-Volmer plot is generally indicative of a single class of fluorophores in a protein, all equally accessible to the quencher; this also means that only one mechanism of quenching occurs (dynamic or static). In the cases of a static mechanism, there is a complex formation, and in such cases, the bimolecular quenching constant is calculated; $k_{\mathrm{q}}$ can be calculated by the ratio between $K_{\mathrm{SV}}$ and $\tau_{0}$. For BSA, the lifetime of the fluorophore is approximately $5 \mathrm{~ns}$ (Lakowicz, 1999) and, for $\alpha$-amylase, the lifetime of the fluorophore is approximately $2.97 \mathrm{~ns}$ (Prendergast, Lu, \& Callahan, 1983).

The maximum value possible for diffusion-limited quenching in water is $\sim 10^{10} \mathrm{M}^{-1} \mathrm{~s}^{-1}$. When the value of the bimolecular quenching constant is higher, it could mean that there is a complex formation between protein and quencher, corresponding to a static mechanism. There have been several studies reporting BSA quenching due to specific interactions (Johansson, 1997) and, in these cases, the quenching constant has been much higher than the maximum value of diffusion-limited quenching in water. Smaller values of $k_{\mathrm{q}}$ can result from steric shielding of the fluorophore.

In many cases, the fluorophore can be quenched by both collision and complex formation with the same quencher. In other cases, an upward curvature indicates the presence of a sphere of action. This assumes the existence of a sphere of volume around a fluorophore, within which a quencher will cause quenching with a probability of 1 . When this is the case, the Stern-Volmer plot exhibits an upward curvature, concave toward the $y$-axis at high $[Q]$, and $F / F_{0}$ is related to $[Q]$ by the following modified form of the Stern-Volmer equation

$F_{0} / F=(1+K[Q]) \exp ([Q] V N / 1000)$

In this equation, $V$ is the volume of the sphere, and $N$ is Avogadro's constant. If $K[Q]$ is small enough, $(1+K[Q]) \approx \exp (K[Q])$, which is equivalent to $\exp ([Q] V N)$ (Lima, Cordeiro Da Silva, de Castro, \& Gameiro, 2007). Thus, the previous equation becomes Eq. (3).

$F_{0} / F=\mathrm{e}^{(K[Q])}$

\subsection{Fluorescence quenching and nephelometry measurements}

A Perkin-Elmer LS 45 fluorimeter was used for fluorescence quenching and nephelometry measurements. For the fluorescence quenching assays the excitation wavelength was set to $290 \mathrm{~nm}$ and the emission spectrum was recorded from 300 to $500 \mathrm{~nm}$. Both slits were $10 \mathrm{~nm}$. For nephelometry analysis, the fluorimeter was used as a $90^{\circ}$ light scattering photometer; for that, both excitation and emission wavelengths selected were the same $(400 \mathrm{~nm})$. At this wavelength, protein and tannins do not absorb the incident light (Carvalho et al., 2006).

The fluorescence quenching experiments were performed in $100 \mathrm{mM}$ acetate buffer with $12 \%$ ethanol/water (v/v) at $\mathrm{pH} 5.0$. It is already known that BSA and $\alpha$-amylase interactions with polyphenols are strong at this pH (Soares et al., 2009). Stock solutions of BSA and $\alpha$-amylase ( $20 \mu \mathrm{M})$ and procyanidin extracts (1:10) were prepared in this solvent. All solutions were carefully filtered $(0.45 \mathrm{~nm})$. To $2 \mathrm{ml}$ microtubes, BSA solution $(75 \mu \mathrm{l})$ and different volumes of seed extracts were added (from 0 to $200 \mu \mathrm{l}$ ); to complete to the final volume $(500 \mu \mathrm{l})$ of acetate buffer were added. In $\alpha$-amylase assays, the final volume was $100 \mu \mathrm{l}$, and $15 \mu \mathrm{l}$ of $\alpha$-amylase solution were added to different volumes of procyanidin extracts from 0 to $30 \mu \mathrm{l}$. All solvents were vortexed for $10 \mathrm{~s}$ and immersed in an ice-bath. The change in fluorescence emission intensity was measured within 1 min of adding seed extracts to proteins. A blank was done for each polyphenol concentration, in which protein solution was replaced only by acetate buffer. The blank spectrum was automatically subtracted from the emission spectrum of the corresponding solution. The cell was thoroughly rinsed to avoid contamination among samples.

Nephelometry assays were carried out with BSA. This experiment was also performed in $100 \mathrm{mM}$ acetate buffer, BSA solution $(50 \mu \mathrm{l})$ and different volumes of seed extract $(1: 20)$ were mixed (from 0 to $70 \mu \mathrm{l}$ ); the final volume was $500 \mu \mathrm{l}$. The mixture was allowed to stand $30 \mathrm{~min}$, and the blank was measured before the addition of BSA stock solution.

A complementary nephelometry assay was carried out in BSA, using a HACH $2100 \mathrm{~N}$ laboratory turbidimeter. To $2800 \mu \mathrm{l}$ of
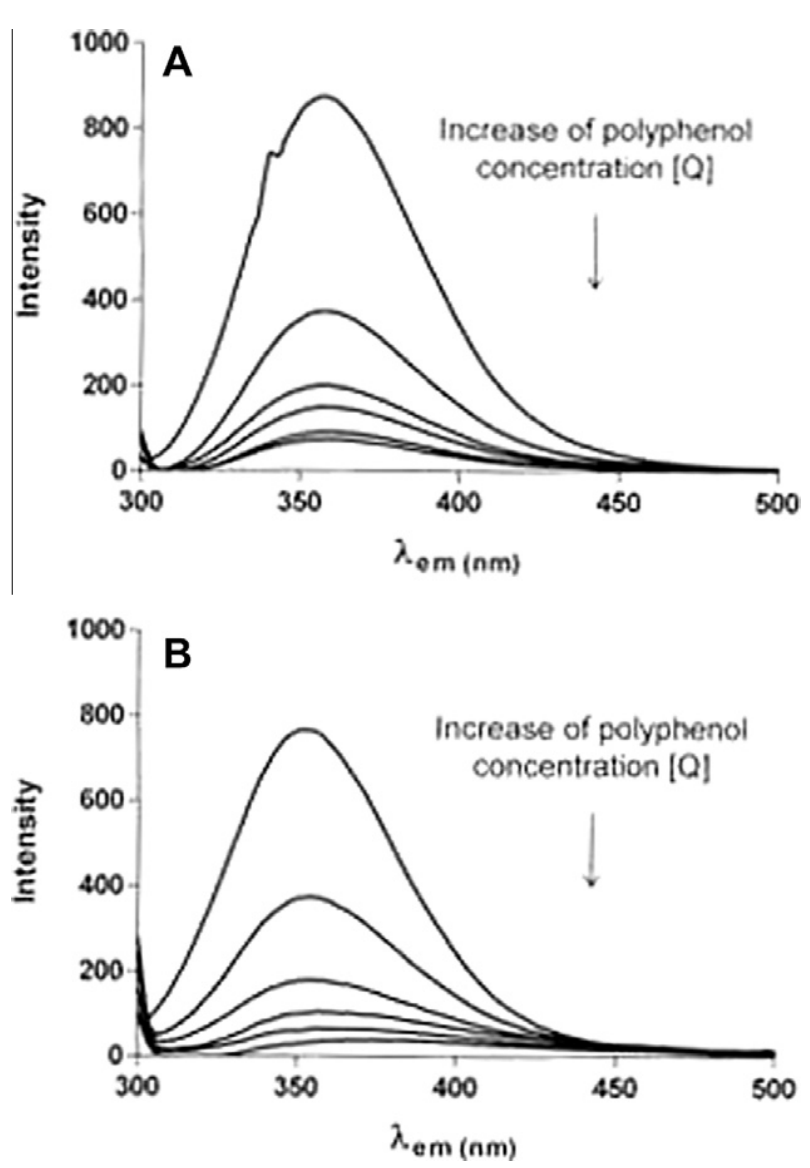

Fig. 1. Emission spectra of $\alpha$-amylase (A) and BSA (B) $3 \mu \mathrm{M}$ at $\lambda_{\text {ex }} 290 \mathrm{~nm}$ (pH 5.0) in the presence of different concentrations of grape seed procyanidins $[Q]$. 


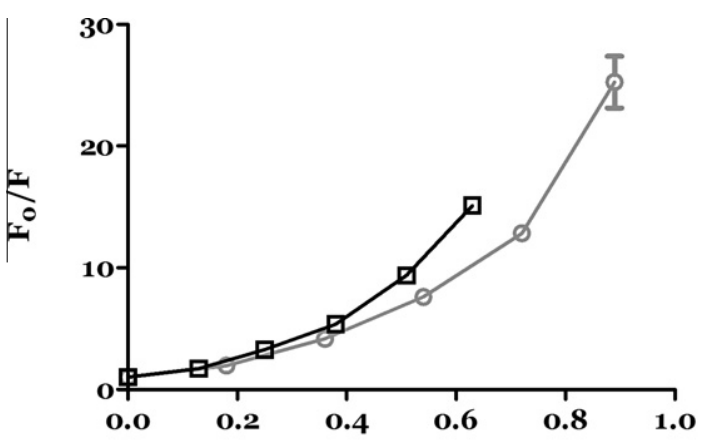

(+) - Catechin (mM)

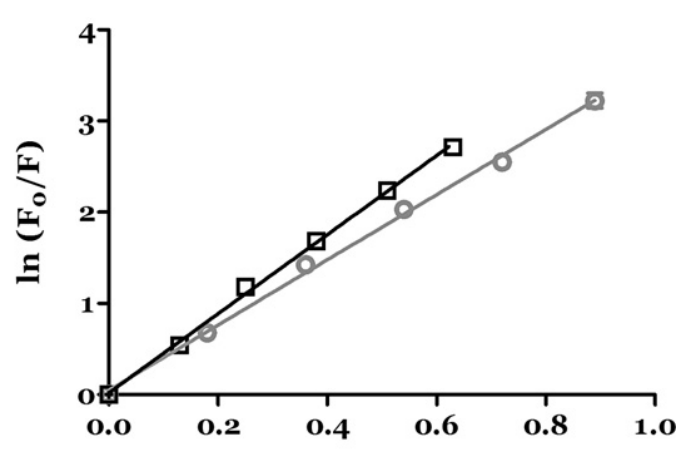

$(+)$ - Catechin (mM)

Fig. 2. Sterm-Volmer plot (left) and modified Sterm-Volmer plot (right) describing tryptophan quenching of BSA ( $3 \mu \mathrm{M}$ ) at pH 5 in presence of different concentrations of seed extracts according their degree of maturity. Black line: ripe seed extract. Grey line: unripe seed extract.

$100 \mathrm{mM}$ acetate buffer, and $200 \mu \mathrm{l}$ of seed extract were added and a blank was measured. Then $100 \mu$ l of BSA solution stock were added and vortexed for $10 \mathrm{~s}$. The mixture was allowed to stand for $30 \mathrm{~min}$; after this the measurement was made. Results were expressed in nephelometric turbidity units (NTU $\mathrm{ml}^{-1}$ seed extract). All experiments were performed in triplicate, and then mean and standard deviations were calculated.

\subsection{Sensory analysis}

Sensory properties of seeds were evaluated with the use of a sensory panel. The panel consisted of eleven non-smoker subjects, seven women and four men. Prior to their participation in the experiments, all subjects were trained to recognize and rate the perceived intensity of astringency, using a standard solution of aluminium potassium sulphate $\left(0.3,0.45,0.6\right.$ and $\left.0.9 \mathrm{~g} \mathrm{l}^{-1}\right)$. During training sessions, subjects were asked when they began to feel some taste or mouth sensation. Moreover, they had to order different concentrations and to perform duo-trio tests. Some panellists had experience in this kind of tasting but the others were instructed to sip the sample, to practise the same number of chews and to rate the intensity. Astringency and tannic intensity were evaluated according to Rousseau and Delteil (2000) at two different stages of ripening for two vintages and two vineyards.

\section{Results and discussion}

\subsection{Fluorescence quenching}

The conformational changes of $\alpha$-amylase and BSA were evaluated by measurement of the intrinsic fluorescence intensity of tryptophan residues before and after the addition of grape seed extracts. Fluorescence quenching of $\alpha$-amylase and BSA complexes in the presence of increasing concentrations of procyanidins of grape seeds was evaluated at different stages of ripening. Fig. 1 shows the fluorescence emission spectrum (at $\lambda_{\text {ex }} 290 \mathrm{~nm}$ ) obtained for $\alpha$ amylase and BSA ( $\mathrm{pH}$ 5.0) upon addition of different concentrations of seed extracts (the quencher $[Q]$ ). A decrease in the fluorescence intensity, caused by quenching, was observed, but there was no shift of the maximum $\lambda_{\mathrm{em}}$. This indicates that the molecular conformation of the protein was not affected, whatever the flavonoid mechanism of interaction. All spectra were corrected by subtracting the spectra of quencher fluorescence. This mode of correction has already been validated (Papadopoulou et al., 2005). The extinction of tryptophans strongly decreased in both $\alpha$-amylase and BSA which demonstrated that grape seed extracts had good affinity for proteins.
Table 1

Apparent static (Kapp) and biomolecular (Kq) quenching constants for the interactions of grape seed extracts with BSA and $\alpha$-amylase at $\mathrm{pH}$ 5.0. Different letters denote significant differences $(p<0.05)$.

\begin{tabular}{|c|c|c|c|c|c|}
\hline & \multicolumn{2}{|l|}{$K_{\text {app }}\left(\mathrm{M}^{-1}\right)$} & & \multicolumn{2}{|c|}{$\underline{K_{\mathrm{q}} \times 10^{11}\left(\mathrm{M}^{-1} \mathrm{~s}^{-1}\right)}$} \\
\hline & Post-veraison & Harvest & & Post-veraison & Harvest \\
\hline \multicolumn{6}{|c|}{ Vineyard 1} \\
\hline \multicolumn{6}{|c|}{ BSA } \\
\hline 2008 & $2850 \pm 110^{\mathrm{a}, \mathrm{b}}$ & $3015 \pm 83^{b, c}$ & 2008 & $5.70 \pm 0.22^{\mathrm{a}, \mathrm{b}}$ & $6.03 \pm 0.17^{b, c}$ \\
\hline 2009 & $2703 \pm 140^{\mathrm{a}}$ & $3066 \pm 37^{\mathrm{b}, \mathrm{c}}$ & 2009 & $5.41 \pm 0.28^{a}$ & $6.13 \pm 0.07^{\mathrm{b}, \mathrm{c}}$ \\
\hline \multicolumn{6}{|c|}{ Vineyard 2} \\
\hline 2008 & $3243 \pm 39^{c}$ & $3929 \pm 129^{\mathrm{e}}$ & 2008 & $6.48 \pm 0.08^{\mathrm{c}, \mathrm{d}}$ & $7.86 \pm 0.26^{\mathrm{d}, \mathrm{e}}$ \\
\hline 2009 & $3564 \pm 120^{d}$ & $4319 \pm 16^{\mathrm{f}}$ & 2009 & $7.13 \pm 0.24^{\mathrm{e}}$ & $8.64 \pm 0.03^{f}$ \\
\hline \multicolumn{6}{|c|}{$\alpha$-Amylase } \\
\hline \multicolumn{6}{|c|}{ Vineyard 1} \\
\hline 2008 & $1812 \pm 37^{\mathrm{a}}$ & $2472 \pm 164^{b}$ & 2008 & $6.10 \pm 0.12^{\mathrm{a}}$ & $8.32 \pm 0.55^{\mathrm{b}}$ \\
\hline 2009 & $3014 \pm 122^{c}$ & $3160 \pm 143^{c}$ & 2009 & $10.1 \pm 0.41^{\mathrm{c}}$ & $10.64 \pm 0.48^{c}$ \\
\hline \multicolumn{6}{|c|}{ Vineyard 2} \\
\hline 2008 & $1919 \pm 88^{\mathrm{a}}$ & $2280 \pm 15^{b}$ & 2008 & $6.46 \pm 0.30^{\mathrm{a}}$ & $7.68 \pm 0.05^{\mathrm{b}}$ \\
\hline 2009 & $2453 \pm 43^{b}$ & $2905 \pm 94^{c}$ & 2009 & $8.26 \pm 0.15^{\mathrm{b}}$ & $9.8 \pm 0.32^{\mathrm{c}}$ \\
\hline
\end{tabular}

Table 2

Tannin specific activities (NTU ml ${ }^{-1}$ seed extracts) of seed extracts towards BSA at pH 5.0 (A) and nephelometry measurements (slope) with different concentrations of polyphenols (B). Different letters denote significant differences $(p<0.05)$.

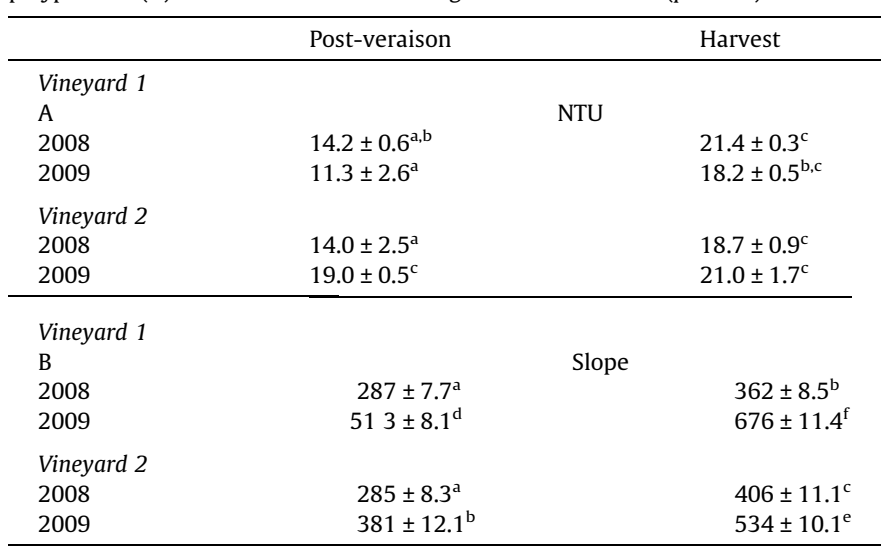

Fig. 2 shows the Sterm-Volmer plot for the BSA fluorescence quenching for ripe and unripe seed extracts. The Sterm-Volmer plot presented has an upward curvature, concave toward the $y$ axis at high $[Q]$. This feature could mean that the fluorophore is being quenched by both mechanisms, dynamic and static, or also the existence of a "sphere of action". With both BSA and $\alpha$-amylase, the quenching of fluorescence obeys the modified Sterm-Volmer equation (Eq. (3)) described previously. Table 1 summarizes the 
Table 3

Polyphenol total index (PTI) measured at $280 \mathrm{~nm}$ and HPLC analysis (mg-g-1 of seed) at post-veraison and harvest stages.

\begin{tabular}{|c|c|c|c|c|c|}
\hline \multirow[t]{2}{*}{$\begin{array}{l}\text { Abs. } \\
280 \mathrm{~nm}\end{array}$} & \multicolumn{2}{|c|}{$\begin{array}{l}\text { PTI (polyphenol total } \\
\text { index) }\end{array}$} & \multirow[t]{2}{*}{ HPLC } & \multicolumn{2}{|c|}{$\mathrm{mg} \mathrm{g}^{-1}$ of seed } \\
\hline & $\begin{array}{l}\text { Post- } \\
\text { veraison }\end{array}$ & Harvest & & $\begin{array}{l}\text { Post- } \\
\text { veraison }\end{array}$ & Harvest \\
\hline \multicolumn{6}{|l|}{ Vineyard 1} \\
\hline 2008 & $0.95 \pm 0.03$ & $0.77 \pm 0.02$ & 2008 & $62.1 \pm 2.8$ & $29.8 \pm 1.0$ \\
\hline 2009 & $0.63 \pm 0.01$ & $0.53 \pm 0.05$ & 2009 & $34.1 \pm 2.8$ & $25.5 \pm 4.9$ \\
\hline \multicolumn{6}{|l|}{ Vineyard 2} \\
\hline 2008 & $0.94 \pm 0.03$ & $0.77 \pm 0.02$ & 2008 & $64.4 \pm 1.3$ & $30.7 \pm 0.5$ \\
\hline 2009 & $0.73 \pm 0.03$ & $0.55 \pm 0.05$ & 2009 & $44.0 \pm 0.9$ & $29.4 \pm 0.9$ \\
\hline
\end{tabular}

calculated constants from the modified Sterm-Volmer $\left(K_{\text {app }}\right)$ and the bimolecular constant $\left(K_{\mathrm{q}}\right)$. The bimolecular constant allows establishing that the quenching is due to a complex formation with proteins that affect tryptophan's microenvironment. The $K_{q}$ of the extracts was always higher than $10^{10} \mathrm{M}^{-1} \mathrm{~s}^{-1}$ which suggests a complex formation between the extracts of seeds and these proteins. In most instances, $K_{\text {app }}$ values show significant differences between the two degrees of ripening studied. Generally, BSA ob-
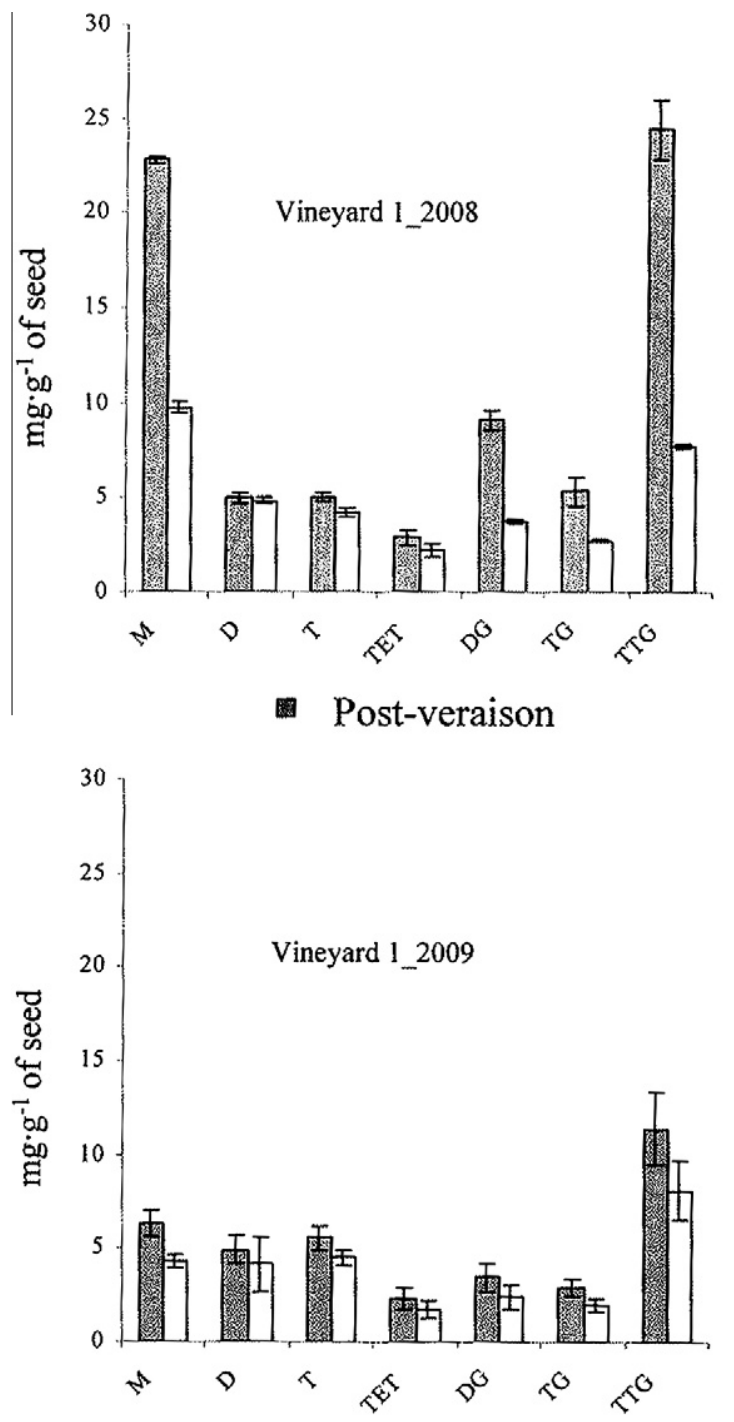

tained $K_{\text {app }}$ values are higher than $\alpha$-amylase values, which could explain better selectivity of BSA (to bind polyphenols). It is worth mentioning that other authors have found values of Sterm-Volmer quenching constants higher in $\alpha$-amylase than BSA with isolated phenolic compounds (Soares et al., 2009).

\subsection{Nephelometry measurements}

This technique was used to assay the influence of the seed ripening on their ability to form protein-tannin insoluble aggregates. The increase in the concentration of polyphenols always produces a greater increase in the relative intensity when the seeds are ripe (Table 2A). A nephelometry constant value was obtained directly from the slope of intensity $v s$. concentration of seed extract (Table $2 \mathrm{~B})$. The higher values were always found in the riper extract and all of them show significant differences. The assay using an $\mathrm{HACH}$ $2100 \mathrm{~N}$ laboratory turbidimeter also confirmed these results.

\subsection{Chemical analysis}

Up to 38 phenolic compounds were identified by HPLC-DADMS and they were grouped, taking into account their degree of
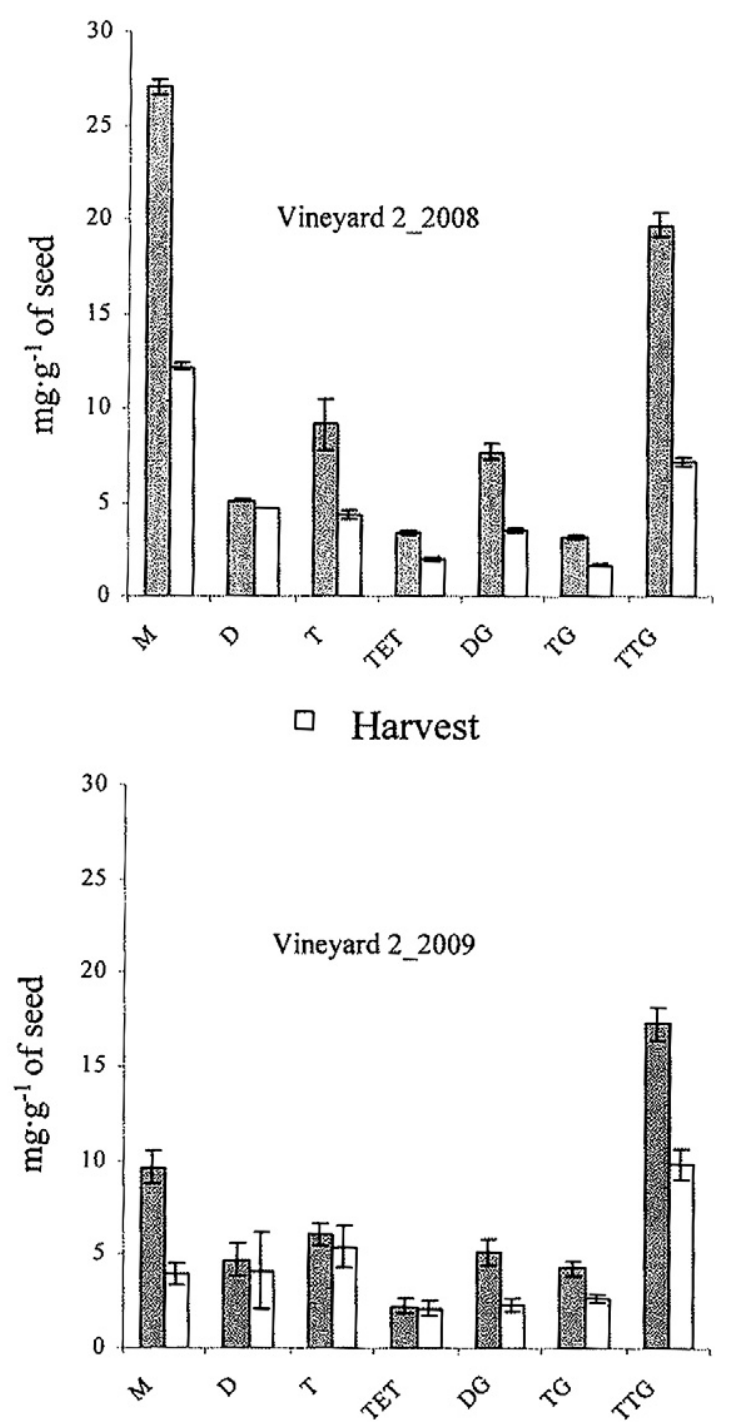

Fig. 3. Content of the main catechins and procyanidins present in the seed extracts determined by HPLC-DAD-MS. Abbreviations: M, monomers; D, dimers; T, trimers; TET, tetramers; DG, galloylated dimers; TG, galloylated trimers; and TTG, total galloylated. 


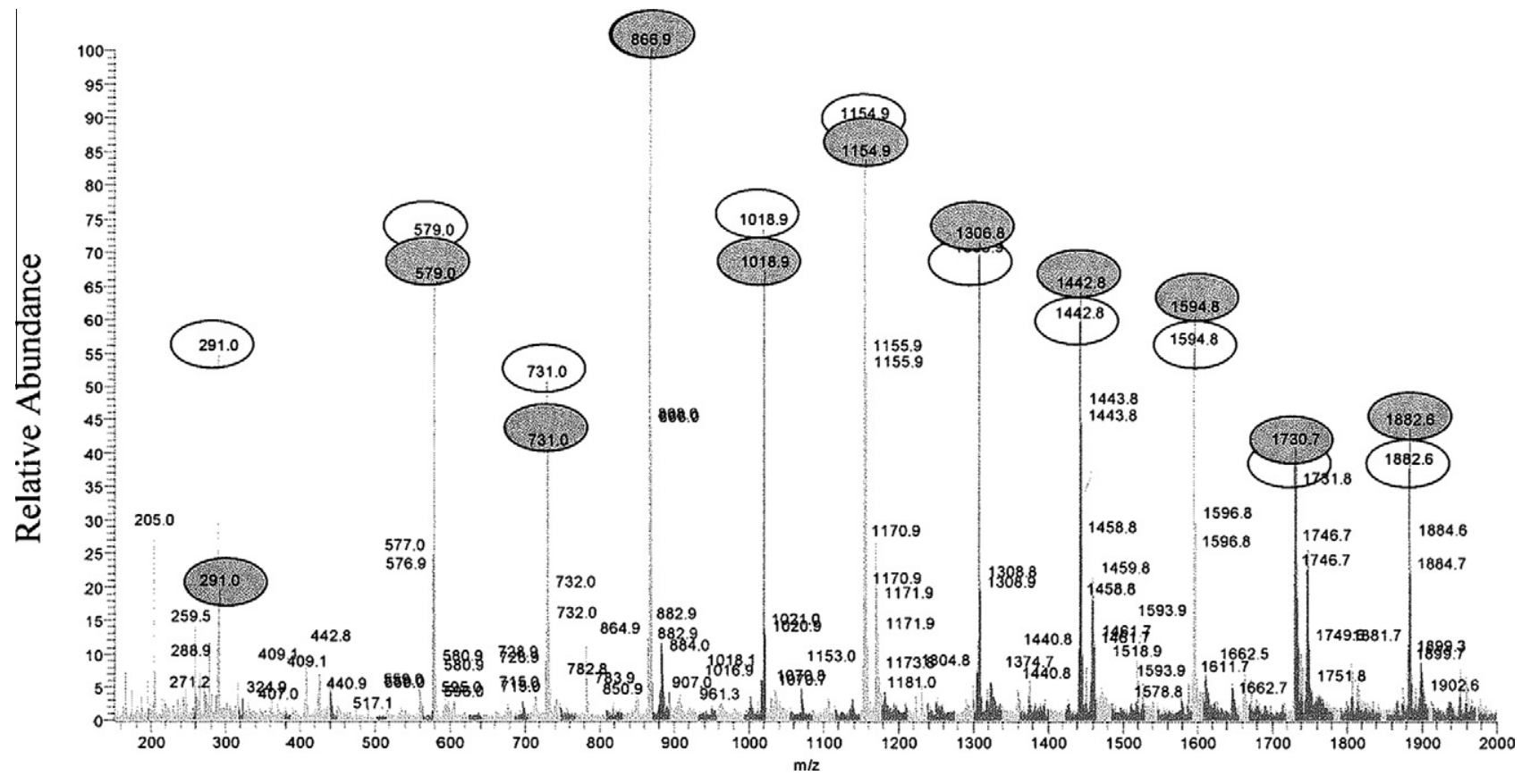

Fig. 4. Relative abundance in mass spectrometry analysis of phenolic compounds in the seed extracts. Grey: harvest, White: post-veraison.

polymerization and galloylation. In general, the contents of procyanidins of seeds reach a maximum in veraison and then there is a decrease and stabilization up to the time of harvest (De Freitas \& Glories, 1999; De Freitas et al., 2000; Downey et al., 2003; Kennedy et al., 2000). Table 3 shows the polyphenol total index (PTI) measured at $280 \mathrm{~nm}$ and total polyphenols ( $\mathrm{mg} \mathrm{g}^{-1}$ of seed) quantified by HPLC-DAD. According to both techniques, the larger content of phenolic compounds always corresponds (with significant difference) to the post-veraison time. Fig. 3 shows the contents of main oligomeric proanthocyanidins in seeds at post-veraison and harvest (unripe and ripe); monomers are generally the major flavanol, as previously reported (Da Silva et al., 1991; De Freitas, Glories, Bourgeois, \& Vitry, 1998; Escribano-Bailón et al., 1992; Kennedy et al., 2000; Santos-Buelga et al., 1995). Monomers and total galloylated compounds showed the greatest variations, decreasing to $42 \%$ and $48 \%$, respectively, in 2008 . Dimers, trimers and tetramers show little variation during maturation.

A larger phenolic content does not seem to involve a larger affinity towards proteins (Tables $1-3$ ). This result could show the importance of the qualitative profile of grape seed extracts for their ability to form tannin-protein aggregates. The size and structural features, such as the presence of galloyl groups, affects the affinities to bind to proteins and the environment of tryptophan residues (Mateus \& de Freitas, 2001; Soares et al., 2009). This ability increases with the rise of molecular weight (increase of catechol moieties) (Charlton et al., 2002; Luck et al., 1994; Porter \& Woodruffe, 1984; Saito, Toki, Suga, \& Honda, 1998; Soares et al., 2009). Results obtained show that the degree of ripeness affects the ability of seed proanthocyanidins to bind to proteins. Ripe seeds have more affinity to bind proteins than have unripe seeds, despite their lower content of phenolic compounds.

During ripening, there is a decrease in the proanthocyanidin content of grape seeds. However, this decrease is not homogeneous, occurring mostly for monomeric and galloylated compounds. This reduction in monomeric and galloylated compounds leads to a relative abundance of higher molecular weight compounds at harvest time (Fig. 4). These more polymerized compounds have higher affinity for proteins and could explain the higher reactivity seen with ripe grape seeds, even with a lower tannin content.

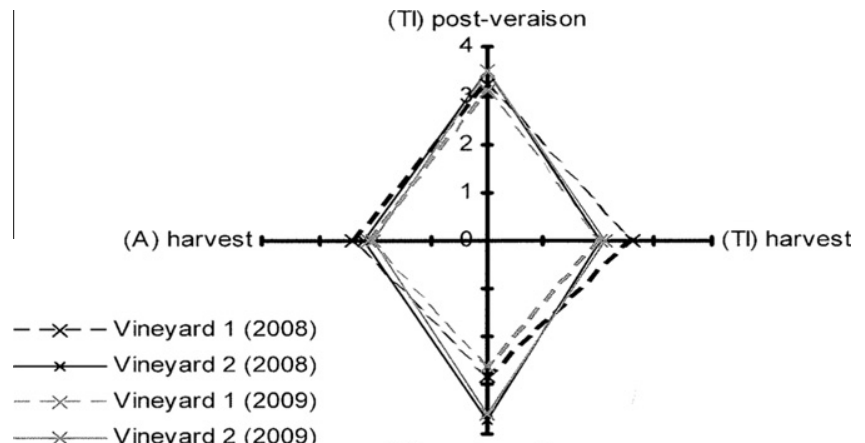

(A) post-veraison

Fig. 5. Sensory analysis of grape seeds at two different stages of maturity Astringency (A) and tannic intensity (TI).

\subsection{Sensory analysis}

Fig. 5 shows the values obtained in sensory analysis, for both, astringency and tannic intensity properties. Differences between post-veraison and harvest time were clearly observed. The results also illustrate differences in vintages and vineyards studied. It is noticeable that 2008 was a vintage more astringent and tannic than was 2009. Also, vineyard 1 showed slightly lower values than did vineyard 2.

A higher ability of grape seed extracts to bind to proteins when the seeds are ripe could lead to the conclusion that these are more astringent but this is not the case. The sensory analysis shows, therefore, an inverse relationship with fluorescence quenching and nephelometry measurements. An explanation could be that, as seeds ripen, their tannins increase in molecular mass, which likely relates to an increase in hydrophobicity of the molecules and this increases protein affinity. Also, it may be possible that the tannin-protein interaction is not the only explanation for the complex sensation of astringency. Note, for instance, the effect that carbohydrates from grapes have on the interaction between tannins and proteins (Carvalho et al., 2006; De Freitas et al., 2003). 

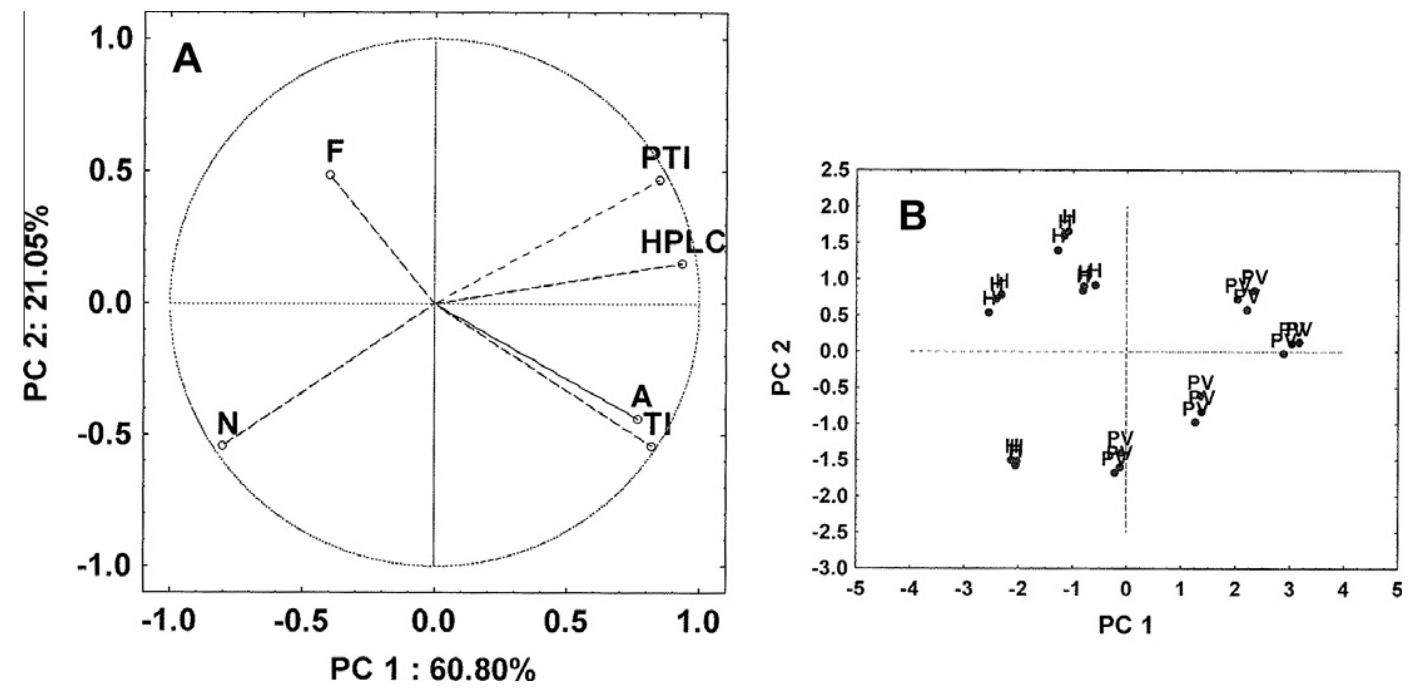

Fig. 6. Representation of the grape seed samples in the loadings plot (A) and in the score plot (B) (PV, post-verasion; $\mathrm{H}$, harvest) on the plane defined by the first and second principal components.

\subsection{Chemometric analysis}

In order to evaluate the relationship between sensory parameters, phenolic composition of grape seed samples, fluorescence and nephelometry, principal components analysis (PCA) was applied. Fig. 6 shows the loading plot (Fig. 6A) on the plane defined by the first and second principal components (Fig. 6B) and also the corresponding projection of samples. The first principal component (PC 1) describes $60.80 \%$ of the variability in the data and the second (PC 2) 21.05\%. The samples are represented at post-veraison (PV) and harvest time (H). The samples are clearly separated in PC 1 (Fig. 6B). It is also noticeable that the $\mathrm{H}$ samples present a homogeneous pattern.

Fig. 6A shows a relationship between astringency (A) and tannic intensity ( $\mathrm{TI}$ ) and, to a lesser extent, between polyphenols total index (PTI) and content of phenolic compounds determined by HPLC-DAD-MS. The loadings plot (Fig. 6A) shows an opposite pattern among sensory properties ( $\mathrm{A}$ and $\mathrm{TI}$ ) and the techniques used to evaluate the interactions of tannin-proteins ( $F$ : fluorescence and $\mathrm{N}$ : nephelometry). Also, an opposite pattern occurs among the contents of phenolic compounds and nephelometry and fluorescence measurements. This pattern suggests that a higher content of phenolic compounds does not involve a major ability to bind to proteins. The grape seeds at harvest time have more of a relationship with fluorescence and nephelometry. However, unripe seeds are more related to sensory properties (Fig. 6A and B).

\section{Conclusions}

Results show that grape seed extracts present good ability to bind to proteins. The association strength of tannin-protein interactions varied with changes to the tannin structure associated with the degree of ripeness. The seed extracts, at harvest stage, showed more ability to bind proteins than at post-veraison time. Therefore, as seeds ripen, their tannins increase in molecular mass, which relates to an increase in hydrophobicity of the molecules and this increases protein affinity. However, this is contrary to reported decrease in astringency of grape seeds during maturity. This could indicate that the tannin-protein interaction is not the single explanation for the complex sensations of astringency of grape seeds.

\section{Acknowledgements}

Thanks are due to the Spanish MICINN and FEDER for financial support (Project ref. AGL2008-05569-C02-01 and AGL2011-30254C02-01) and to Bodegas RODA S.A. (Haro, La Rioja, Spain) for supplying the grape samples.

\section{References}

Buisson, G., Duee, E., Haser, R., \& Payan, F. (1987). Three dimensional structure of porcine pancreatic $\alpha$-amilase at $2.9 \AA$ resolution. Role of calcium in structure and activity. The EMBO Journal, 6, 3909-3916.

Cadot, Y., Minana-Castello, M. T., \& Chevalier, M. (2006). Anatomical, histological, and histochemical changes in grape seeds from Vitis vinifera L. cv cabernet franc during fruit development. Journal of Agricultural and Food Chemistry, 54, 9206-9215.

Canon, F., Giuliani, A., Paté, F., \& Sarni-Manchado, P. (2010). Ability of a salivary intrinsically unstructured protein to bind different tannin targets revealed by mass spectrometry. Analytical and Bioanalytical Chemistry, 398, 815-822.

Carvalho, E., Mateus, N., Plet, B., Pianet, I., Dufourc, E., \& De Freitas, V. (2006). Influence of wine pectic polysaccharides on the interactions between condensed tannins and salivary proteins. Journal of Agricultural and Food Chemistry, 54, 8936-8944.

Charlton, A. J., Baxter, N. J., Khan, M. L., Moir, A. J. G., Haslam, E., Davies, A. P., et al. (2002). Polyphenol/peptide binding and precipitation. Journal of Agricultural and Food Chemistry, 50, 1593-1601.

Da Silva, J. M. R., Rigaud, J., Cheynier, V., Cheminat, A., \& Moutounet, M. (1991). Procyanidin dimers and trimers from grape seeds. Phytochemistry, 30, 1259-1264.

De Freitas, V., Carvalho, E., \& Mateus, N. (2003). Study of carbohydrate influence on protein-tannin aggregation by nephelometry. Food Chemistry, 81, 503-509.

De Freitas, V. A. P., \& Glories, Y. (1999). Concentration and compositional changes of procyanidins in grape seeds and skin of white Vitis vinifera varieties. Journal of the Science of Food and Agriculture, 79, 1601-1606.

De Freitas, V. A. P., Glories, Y., Bourgeois, G., \& Vitry, C. (1998). Characterisation of oligomeric and polymeric procyanidins from grape seeds by liquid secondary ion mass spectrometry. Phytochemistry, 49, 1435-1441.

De Freitas, V. A. P., Glories, Y., \& Monique, A. (2000). Developmental changes of procyanidins in grapes of red Vitis vinifera varieties and their composition in respective wines. American Journal of Enology and Viticulture, 51, 397-403.

Downey, M. O., Harvey, J. S., \& Robinson, S. P. (2003). Analysis of tannins in seeds and skins of Shiraz grapes throughout berry development. Australian Journal of Grape and Wine Research, 9, 15-27.

Elodis, P., Móra, S., \& Krysteva, M. (1972). Investigation of the active center of porcine-prancreatic amylase. European Journal of Biochemistry, 24, 577-582.

Escribano-Bailón, T., Álvarez-García, M., Rivas-Gonzalo, J. C., Heredia, F. J., \& SantosBuelga, C. (2001). Color and stability of pigments derived from the acetaldehyde-mediated condensation between malvidin 3-O-glucoside and (+)-catechin. Journal of Agricultural and Food Chemistry, 49, 1213-1217.

Escribano-Bailón, T., Gutiérrez-Fernández, Y., Rivas-Gonzalo, J. C., \& Santos-Buelga, C. (1992). Characterization of procyanidins of Vitis vinifera variety Tinta del Pais grape seeds. Journal of Agricultural and Food Chemistry, 40, 1794-1799. 
Ferrer-Gallego, R., García-Marino, M., Hernández-Hierro, J. M., Rivas-Gonzalo, J. C., \& Escribano-Bailón, M. T. (2010). Statistical correlation between flavanolic composition, colour and sensorial parameters in grape seed during ripening. Analytica Chimica Acta, 660, 22-28

Fia, G., Dinnella, C., Bertuccioli, M., \& Monteleone, E. (2009). Prediction of grape polyphenol astringency by means of a fluorimetric micro-plate assay. Food Chemistry, 113, 325-330.

Garcia-Marino, M., Rivas-Gonzalo, J. C., Ibañez, E., \& Garcia-Moreno, C. (2006). Recovery of catechins and proanthocyanidins from winery by-products using subcritical water extraction. Analytica Chimica Acta, 563, 44-50.

Gawel, R. (1998). Red wine astringency: A review. Australian Journal of Grape and Wine Research, 4, 74-95.

Green, B. G. (1993). Oral astringency: A tactile component of flavor. Acto Psychologica, 84, 119-125.

Hakkinen, L., Uitto, V.-J., \& Larjava, H. (2000). Cell biology of gingival wound healing. Periodontology, 2000(24), 127-152.

Hofmann, T., Glabasnia, A., Schwarz, B., Wisman, K. N., Gangwer, K. A., \& Hagerman, A. E. (2006). Protein binding and astringent taste of a polymeric procyanidin, 1,2,3,4,6-penta-O-galloyl-b-D-glucopyranose, castalagin, and grandinin. Journa of Agricultural and Food Chemistry, 54, 9503-9509.

Horne, J., Hayes, J., \& Lawless, H. T. (2002). Turbidity as a measure of salivary protein reactions with astringent substances. Chemical Senses, 27, 653-659.

Jackson, R. S (2009). Taste and mouth-feel sensations wine tasting (2nd ed.). San Diego: Academic Press, pp. 129-175.

Johansson, J. S. (1997). Binding of the volatile anesthetic chloroform to albumin demonstrated using tryptophan fluorescence quenching. Journal of Biological Chemistry, 272, 17961-17965.

Jordao, A. M., Ricardo Da Silva, J. M., \& Laureano, O. (2001). Evolution of catechins and oligomeric procyanidins during grape maturation of Castelao Frances and Touriga Francesa. American Journal of Enology and Viticulture, 52, 230-234.

Kallithraka, S., Bakker, J., \& Clifford, M. (1997). Evaluation of bitterness and astringency of $(+)$-catechin and (-)-epicatechin in red wine and in model solution. Journal of Sensory Studies, 12, 25-37.

Kallithraka, S., Bakker, J., \& Clifford, M. N. (1998). Evidence that salivary proteins are involved in astringency. Journal of Sensory Studies, 13, 29-43.

Kennedy, J. A., Matthews, M. A., \& Waterhouse, A. L. (2000). Changes in grape seed polyphenols during fruit ripening. Phytochemistry, 55, 77-85.

Khanbabaee, K., \& van Ree, T. (2001). Tannins: Classification and definition. Natura Product Reports, 18, 641-649.

Lakowicz, J. R. (1999). Principles of fluorescence spectroscopy. New York: Kluwer Academic/Plenum Publishers.

Le Moigne, M., Maury, C., Bertrand, D., \& Jourjon, F. (2008). Sensory and instrumental characterisation of Cabernet Franc grapes according to ripening stages and growing location. Food Quality and Preference, 19, 220-231.

Lima, S. A. C., Cordeiro Da Silva, A., de Castro, B., \& Gameiro, P. (2007). Sensitivity of P-glycoprotein tryptophan residues to benzodiazepines and ATP interaction. Biophysical Chemistry, 125, 143-150.

Luck, G., Liao, H., Murray, N. J., Grimmer, H. R., Warminski, E. E., Williamson, M. P., et al. (1994). Polyphenols, astringency and proline-rich proteins. Phytochemistry, 37, 357-371.

Mateus, N., \& de Freitas, V. (2001). Evolution and stability of anthocyanin-derived pigments during port wine aging. Journal of Agricultural and Food Chemistry, 49 5217-5222.

Mateus, N., Pinto, R., Ruão, P., \& de Freitas, V. (2004). Influence of the addition of grape seed procyanidins to Port wines in the resulting reactivity with human salivary proteins. Food Chemistry, 84, 195-200

McRae, J. M., Falconer, R. J., \& Kennedy, J. A. (2010). Thermodynamics of grape and wine tannin interaction with polyproline: Implications for red wine astringency. Journal of Agricultural and Food Chemistry, 58, 12510-12518.

McRae, J. M., \& Kennedy, J. A. (2011). Wine and grape tannin interactions with salivary proteins and their impact on astringency: A review of current research. Molecules, 16, 2348-2364.

Monteleone, E. Condelli, N., Dinnella, C. \& Bertuccioli, M. (2004). Prediction of perceived astringency induced by phenolic compounds. Food Quality and Preference, 15, 761-769.

Nayak, A., \& Carpenter, G. H. (2008). A physiological model of tea-induced astringency. Physiology \& Behavior, 95, 290-294.

Obreque Slier, E. (2010). Caracterización fenólica de uvas del cultivar carménère y su relación con la sensación de astringencia. Tarragona: Universitat Rovira y Virgili.

Obreque-Slier, E., López-Solís, R., Peña-Neira, Á., \& Zamora-Marín, F. (2010). Tanninprotein interaction is more closely associated with astringency than tanninprotein precipitation: Experience with two oenological tannins and a gelatin. International Journal of Food Science \& Technology, 45, 2629-2636.
Papadopoulou, A., \& Frazier, R. A. (2004). Characterization of protein-polyphenol interactions. Trends in Food Science \& Technology, 15, 186-190.

Papadopoulou, A., Green, R. J., \& Frazier, R. A. (2005). Interaction of flavonoids with bovine serum albumin: A fluorescence quenching study. Journal of Agricultura and Food Chemistry, 53, 158-163.

Pasero, L., Mazzei-Pierron, Y., Abadie, B., \& Chicheportiche, Y. (1986). Complete amino acid sequence and location of the 5 disulphide bridges in porcine pancreas a-amilase. Biochimica et Biophysica Acta, 8869, 147-157.

Passos, C. P., Cardoso, S. M., Barros, A. S., Silva, C. M., \& Coimbra, M. A. (2010) Application of Fourier transform infrared spectroscopy and orthogonal projections to latent structures/partial least squares regression for estimation of procyanidins average degree of polymerisation. Analytica Chimica Acta, 661 143-149.

Payne, C., Bowyer, P. K., Herderich, M., \& Bastian, S. E. P. (2009). Interaction of astringent grape seed procyanidins with oral epithelial cells. Food Chemistry, 115, 551-557.

Petrovic, S. C. (2009). Correlation of perceived wine astringency to cyclic voltammetric response. American Journal of Enology and Viticulture, 60, 373-378.

Porter, L. J., \& Woodruffe, J. (1984). Haemanalysis: The relative astringency of proanthocyanidin polymers. Phytochemistry, 23, 1255-1256.

Prendergast, F. G., Lu, J., \& Callahan, P. J. (1983). Oxygen quenching of sensitized terbium luminescence in complexes of terbium with small organic ligands and proteins. Journal of Biological Chemistry, 258, 4075-4078.

Prieur, C., Rigaud, J., Cheynier, V., \& Moutounet, M. (1994). Oligomeric and polymeric procyanidins from grape seeds. Phytochemistry, 36, 781-784.

Prigent, S. V. E., Voragen, A. G. J., van Koningsveld, G. A., Baron, A., Renard, C. M. G. C. \& Gruppen, H. (2009). Interactions between globular proteins and procyanidins of different degrees of polymerization. Journal of Dairy Science, 92, 5843-5853.

Prinz, J. F., \& Lucas, P. W. (2000). Saliva tannin interactions. Journal of Oral Rehabilitation, 27, 991-994.

Rawel, H. M., Frey, S. K., Meidtner, K., Kroll, J., \& Schweigert, F. J. (2006). Determining the binding affinities of phenolic compounds to proteins by quenching of the intrinsic tryptophan fluorescence. Molecular Nutrition $\mathcal{E}$ Food Research, 50 705-713.

Ricardo Da Silva, J. M., Rosec, J. P., Bourzeix, M., Mourgues, J., \& Moutonet, M. (1992) Dimer and trimer procyanidins in Carignan and Mourvedre grapes and red wines. Vitis, 31, 55-63.

Romeyer, F. M., Macheix, J. J., \& Sapis, J. C. (1986). Changes and importance of oligomeric procyanidins during maturation of grape seeds. Phytochemistry, 25, 219-221.

Rossetti, D., Bongaerts, J. H. H., Wantling, E., Stokes, J. R., \& Williamson, A. M. (2009). Astringency of tea catechins: More than an oral lubrication tactile percept. Food Hydrocolloids, 23, 1984-1992.

Rousseau, J., \& Delteil, D. (2000). Présentation d'une méthode d'analyse sensorielle des raisins. Principe, méthode et grille d'interprétation. Revue Française d'Oenologie, 183, 10-13.

Sáenz-Navajas, M. P., Ferreira, V., Dizy, M., \& Fernández-Zurbano, P. (2010) Characterization of taste-active fractions in red wine combining HPLC fractionation, sensory analysis and ultra performance liquid chromatography coupled with mass spectrometry detection. Analytica Chimica Acta, 673, 151-159.

Saito, N., Toki, K., Suga, A., \& Honda, T. (1998). Acylated pelargonidin 3,7-glycosides from red flowers of Delphinium hybridum. Phytochemistry, 49, 881-886.

Santos-Buelga, C., Francia-Aricha, E. M., \& Escribano-Bailón, M. T. (1995) Comparative flavan-3-ol composition of seeds from different grape varieties. Food Chemistry, 53, 197-201.

Schwarz, B., \& Hofmann, T. (2008). Is there a direct relationship between ora astringency and human salivary protein binding? European Food Research and Technology, 227, 1693-1698.

Soares, S. I., Gonçalves, R. M., Fernandes, I., Mateus, N., \& de Freitas, V. (2009) Mechanistic approach by which polysaccharides inhibit $\alpha$-amylase/procyanidin aggregation. Journal of Agricultural and Food Chemistry, 57, 4352-4358.

Souquet, J. M., Cheynier, V., Brossaud, F., \& Moutounet, M. (1996). Polymeric proanthocyanidins from grape skins. Phytochemistry, 43, 509-512.

Souquet, J. M., Labarbe, B., Le Guerneve, C., Cheynier, V., \& Moutounet, M. (2000) Phenolic composition of grape stems. Journal of Agricultural and Food Chemistry, $48,1076-1080$.

Sun, B. S., Pinto, T., Leandro, M. C., Ricardo Da Silva, J. M., \& Spranger, M. I. (1999) Transfer of catechins and proanthocyanidins from solid parts of the grape cluster into wine. American Journal of Enology and Viticulture, 50, 179-184.

Tachibana, H., Koga, K., Fujimura, Y., \& Yamada, K. (2004). A receptor for green tea polyphenol EGCG. Nature Structural \& Molecular Biology, 11, 380-381. 